\title{
IMPLEMENTASI KEBIJAKSANAAN "PROSPEK" (PROGRAM STRATEGIS PEMBANGUNAN KAMPUNG) \\ DALAM MEMBERDAYAKAN MASYARAKAT PAPUA MANDIRI DAN SEJAHTERA DI KABUPATEN JAYAPURA PROVINSI PAPUA \\ (Studi Kasus di Distrik Sentani Barat, Sentani, dan Sentani Timur)
}

\author{
Oleh \\ Petrus Nero ${ }^{1}$, \\ Ermaya Suradinata ${ }^{2}$, Deti Mulyati ${ }^{3}$ \\ 1) Pemerintah Daerah Kota Jayapura \\ Program Magister Terapan Studi Pemerintahan Daerah Institut Pemerintahan Dalam Negeri \\ Petrusawiner054@gmail.com \\ ${ }^{2,3)}$ Institut Pemerintahan Dalam Negeri
}

\begin{abstract}
"IMPLEMENTATION POLICY OUTLOOK RISE IN PAPUA SELF EMPOWERMENT AND PROSPEROUS OF REGENCY JAYAPURA, PAPUA PROVINCE"
\end{abstract}

$T$

is research study to provide an overview of Program Policy Implementation Regency

development strategies in community development independent and prosperous Papua rose in Regency Jayapura Papua province, and find solutions that are useful in the effort to do programs in empowering Regency development strategy effectiveness district government officers as one of the implementing public policy implementation in the area.

The design of this study used descriptive qualitative approach in which the researcher wants to describe and explain how the policy implementation strategies village development programs in Papua Revive Self empowerment and Prosperity in Regency, as set in the applicable legislation. Data collection techniques used in this study was to combine the interview with documentation.

Based on the survey results revealed that one of the weaknesses in policy implementation strategies village development program in community development is still weak role both provincial governments have not involved the role of community leaders, religious leaders and traditional leaders and village headmen and the device is still in the process of socialization itu.Pemerintah memorable works by relying on the power hierarki bureaucracy, where the orientation and workshop involves only structural officials at the district level.

Suggestions presented in this research is the development of program strategies village, every year there should be a continuation because the village people are getting better, can fix, and to improve the community in addition to menyejahteraan society must diswadayakan and the village fund program development strategy specific to the needs of the community infrastructure Regency Jayapura.

Keywords: policy implementation, community empowerment 


\begin{abstract}
AbSTRAK
$\mathrm{P}$ enelitian ini bertujuan memberikan gambaran tentang Implementasi Kebijaksanaan Program Strategi Pembangunan Kampung dalam memberdayakan masyarakat Papua "Bangkit Mandiri dan Sejahtera" di Kabupaten Jayapura Provinsi Papua, serta menemukan solusi yang bermanfaat dalam upaya melakukan Program Strategi Pembangunan Kampung dalam pemberdayaan efektivitas aparatur pemerintahan kabupaten sebagai salah satu pelaksana implementasi kebijaksanaan publik di daerah.

Desain penelitian ini menggunakan metode deskriptif dengan pendekatan kualitatif di mana peneliti ingin menggambarkan dan menjelaskan tentang bagaimana implementasi kebijakan Program Strategi Pembangunan Kampung dalam pemberdayaan masyarakat Papua "Bangkit Mandiri dan Sejahtera" di Kabupaten Jayapura sebagaimana di atur dalam perundangundangan yang berlaku. Teknik pengumpulan data yang digunakan dalam penelitian ini adalah dengan mengombinasikan antara wawancara dengan dokumentasi.

Berdasarkan hasil penelitian diketahui bahwa salah satu kelemahan dalam implementasi kebijakan Program Strategi Pembangunan Kampung dalam pemberdayaan masyarakat masih lemahnya peranan pemerintah baik provinsi maupun kabupaten belum melibatkan peran tokoh masyarakat, tokoh agama dan tokoh adat serta kepala kampung dan perangkat kampung dalam proses sosialisasi itu.Pemerintah masih berkesan bekerja dengan mengandalkan kekuasaan hierarki birokrasi, di mana orientasi dan Workshop hanya melibatkan pejabat struktural di tingkat distrik.

Saran yang disampaikan dalam penelitian ini adalah Program Strategi Pembangunan Kampung, setiap tahun harus ada kelanjutan karena masyarakat kampung yang semakin baik, dapat memperbaiki, serta meningkatkan pemberdayaan masyarakat. Di samping itu untuk menyejahteraan masyarakatnya harus diswadayakan dan dalam dana Program Strategi Pembangunan Kampung dikhususkan untuk kebutuhan infrastruktur masyarakat Kabupaten Jayapura.
\end{abstract}

Kata kunci: implementasi kebijakan, pemberdayaan masyarakat

\section{PENDAHULUAN}

$\mathrm{H}^{\mathrm{s}}$ akikat pembangunan nasional adalah pembangunan manusia seutuhnya dan masyarakat seluruhnya, tetapi dalam kenyataannya masih adanya kesenjangan sosial yang belum dapat dipecahkan. Salah satu bentuk masalah sosial yang saat ini masih mengemuka di banyak negara sedang berkembang termasuk Indonesia adalah permasalahan kemiskinan. Secara umum kemiskinan ialah satu keadaan di mana seseorang itu kekurangan bahanbahan keperluan untuk memenuhi kebutuhan hidup.

Di Indonesia walaupun usaha untuk meningkatkan kesejahteraan rakyat sudah dilaksanakan melalui kebijakan pembangunan nasional, dan di dalamnya juga terdapat program pengentasan kemiskinan, akan tetapi jumlah penduduk yang masuk kategori miskin masih cukup besar. Di Indonesia masalah kemiskinan dirasakan sudah sangat mendesak untuk ditangani, khususnya di wilayah perdesaan. Salah satu ciri umum dari kondisi fisik masyarakat miskin adalah tidak memiliki akses ke prasarana dan sarana dasar lingkungan yang memadai, dengan kualitas perumahan dan permukiman yang jauh di bawah standar kelayakan, kualitas pendidikan dan kesehatan yang buruk, dan mata pencaharian yang tidak menentu. Secara umum, pada periode Maret 2012 Maret 2020 tingkat kemiskinan mengalami penurunan, baik dari sisi jumlah maupun persentase. Tercatat persentase penduduk 
miskin pada periode tersebut turun sebesar 4,47 persen poin, yaitu dari 31,11 persen atau berjumlah 920,52 ribu jiwa pada Maret 2012 menjadi 26,64 persen atau 911,37 ribu jiwa pada Maret 2020. Persentase penduduk miskin di Papua selama enam bulan terakhir justru mengalami peningkatan sebesar 0,09 persen poin, yaitu dari 26,55 persen pada September 2019 menjadi 26,64 persen pada Maret 2020. Berbeda jika dibandingkan dengan Maret 2019, terjadi penurunan 0,11 poin persen. Dilihat menurut tipe daerahnya, penduduk miskin di Papua terkonsentrasi di daerah perdesaan, di mana pada Maret 2020 terdapat 867,74 ribu jiwa atau 35,50 persen penduduk miskin tinggal di perdesaan, sedangkan di perkotaan hanya sebesar 43,63 ribu jiwa atau 4,47 persen. Jika dibandingkan dengan kondisi pada periode sebelumnya (September 2019), terdapat penurunan persentase penduduk miskin di daerah perkotaan sebesar 0,06 persen poin. Sedangkan untuk daerah perdesaan persentase penduduk miskin naik sebesar 0,14 persen poin. Tiga provinsi di Kawasan Timur Indonesia, yaitu Provinsi Papua, Papua Barat dan Nusa Tenggara Timur merupakan wilayah dengan persentase penduduk miskin terbesar, yaitu secara berurutan 26,64 persen, 21,37 persen dan 20,90 persen. Persoalan kemiskinan bukan hanya sekadar berapa jumlah dan persentase penduduk miskin. Dimensi lain yang perlu diperhatikan adalah tingkat kedalaman dan keparahan dari kemiskinan. Indeks Kedalaman Kemiskinan adalah ukuran rata-rata kesenjangan pengeluaran masingmasing penduduk miskin terhadap garis kemiskinan. Sedangkan Indeks Keparahan Kemiskinan memberikan gambaran mengenai penyebaran pengeluaran di antara penduduk miskin.

Berdasarkan data Tabel 1 dapat dijelaskan bahwa Provinsi Papua dan Papua Barat masing-masing berada pada urutan pertama dan kedua provinsi dengan tingkat kemiskinan tertinggi. Melihat besarnya jumlah angka kemiskinan di Papua maka permasalahan kemiskinan merupakan permasalahan yang sangat serius yang harus diselesaikan oleh pemerintah khususnya Provinsi Papua.

Beranjak dari pemikiran bahwa pembagian Dana Otsus sepatutnya menggunakan asas keadilan dan pemerataan, serta memperhatikan kinerja output, outcome dan impact yang dihasilkan dalam pengelolaan Dana Otsus sebelumnya (Periode 2002-2013) kurang optimal, maka pada masa pemerintahan Gubernur/Wakil Gubernur Lukas Enembe

Tabel 1. Tingkat Kemiskinan Provinsi Papua Dan Papua Barat (Kabupaten Jayapura, Sarmi, Kerom dan Kota Jayapura)

\begin{tabular}{clcc}
\hline No & $\begin{array}{c}\text { Provinsi/ } \\
\text { Kabupaten/Kota }\end{array}$ & $\begin{array}{c}\text { Jumlah Angka } \\
\text { Kemiskinan (Orang) }\end{array}$ & $\begin{array}{c}\text { Persentase } \\
\text { (\%) }\end{array}$ \\
\hline 1. & Papua & $926.36 \mathrm{ribu}$ & 26,64 \\
2. & Papua Barat & $208.580 \mathrm{ribu}$ & 21,37 \\
3 & Kabupaten Jayapura & $17.19 \mathrm{ribu}$ & 17,19 \\
4 & Kabupaten Sarmi & $5.80 \mathrm{ribu}$ & 5,8 \\
5 & Kota Keerom & $9.55 \mathrm{ribu}$ & 9,55 \\
6 & Kota Jayapura & $34.42 \mathrm{ribu}$ & 34,42 \\
\hline
\end{tabular}

Sumber: Badan Pusat Statistik Nasional, 2020 
dan Klemen Tinal (2013-2018) pembagian Dana Otsus diubah menjadi $80 \%$ untuk Pemerintah Kabupaten/kota dan 20\% untuk pemerintah provinsi. Pembagian tersebut setelah terlebih dahulu mengalokasikan dana untuk Urusan Bersama, yaitu Program Gerbangmas Hasrat Papua, Kartu Papua Sehat, Perumahan Rakyat, dan "Prospek". Harapannya, melalui alokasi Dana Otsus seperti itu semua Pemerintah Kabupaten/ kota akan menjadi lebih leluasa berkreasi dan berinovasi untuk mengelola Dana Otsus dalam upaya mempercepat kemajuan wilayah Papua dibandingkan wilayah lainnya di Indonesia. Harapan lainnya adalah untuk mempercepat peningkatan kesejahteraan masyarakat Papua menjadi di atas rata-rata nasional, serta untuk semakin memperluas kesempatan atau peluang usaha bagi Orang Asli Papua, sebagaimana yang diamanatkan oleh Undang-Undang No. 21 Tahun 2001 mengenai Otonomi Khusus Provinsi Papua.
Selanjutnya untuk memastikan bahwa pengelolaan Dana Otsus dilaksanakan sesuai yang diharapkan, maka pada akhir tahun 2013 telah disahkan Perdasus No. 25 Tahun 2013 tentang Pembagian Penerimaan dan Pengelolaan Keuangan Dana Otonomi Khusus, yang diikuti dengan turunannya baik itu pada 2013, 2014 maupun 2015 dalam berbagai bentuk Peraturan Gubernur dan Surat Keputusan Gubernur seperti Peraturan Gubernur tentang jaminan pembiayaan pelayanan kesehatan masyarakat Papua, sistem rujukan pelayanan kesehatan, penggunaan Dana Otsus Untuk Pendidikan, "Prospek", Gerbangmas, pedoman pengelolaan Dana Otsus, dan sebagainya, atau Surat Keputusan Gubernur tentang bantuan untuk lembaga keagamaan, bantuan sosial kepada Fasyankes, penerima belanja program strategi pembangunan ekonomi dan kelembagaan kampung, dan lain-lain.

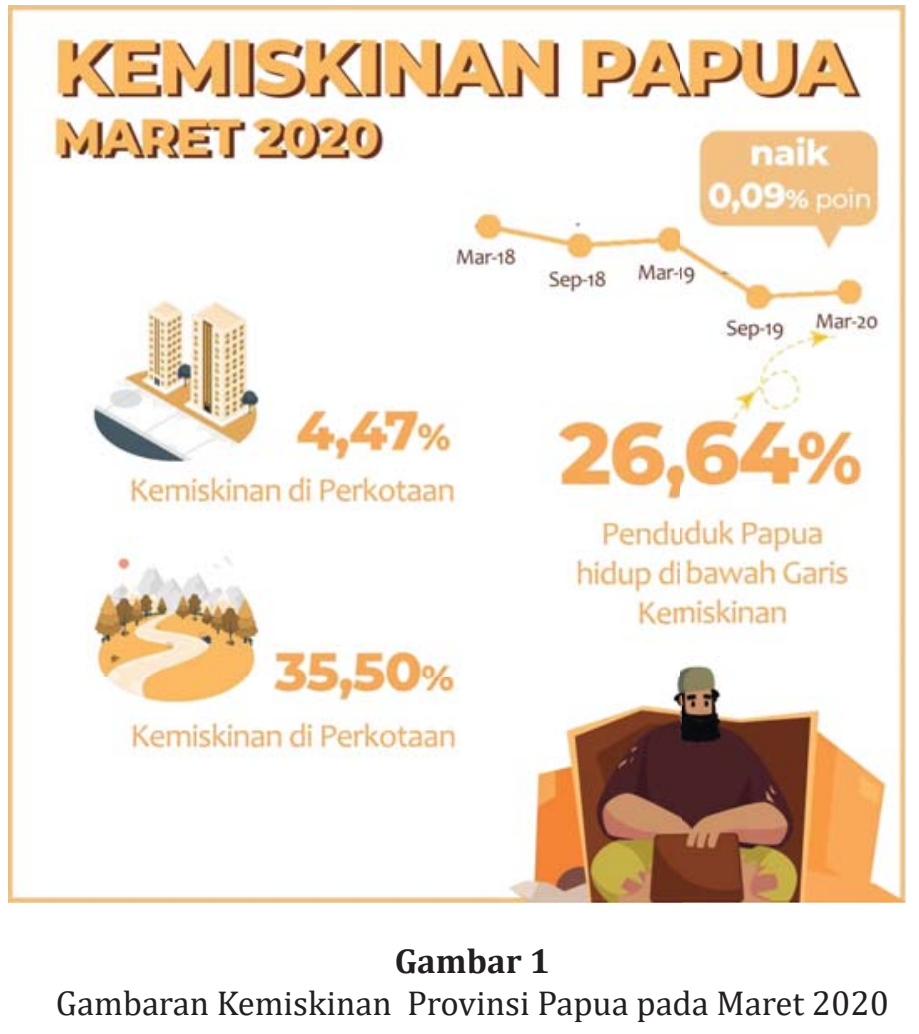

Sumber: Badan Pusat Statistik Nasional (2020) 
Pemberian kewenangan yang lebih luas tersebut berarti pula tanggung jawab yang lebih besar bagi Pemerintah Provinsi Papua dan Pemerintah Kabupaten/Kota serta rakyat Papua, untuk memberdayakan semua lapisan masyarakat yang berada di kampungkampung. Untuk pilar-pilar reformasi pelaksanaan pemerintahan dan fiskal daerah, yakni, demokrasi, desentralisasi dan partisipasi masyarakat menjadi dasar sekaligus tujuan dalam pelaksana Program Pembangunan Kampung (PPK).

Provinsi Papua mempunyai kekayaan alam yang sangat melimpah tetapi pada kenyataannya Provinsi Papua masih daerah termiskin No. satu (1) di Indonesia sangat disayangkan Dana Otonomi Khusus yang diberikan Pemerintah Pusat sebesar 4,5 triliun setiap tahun tidak ada implementasinya. Masalah yang diteliti oleh peniliti cukup luas,sehingga penelitian ini merupakan penelitian bentuk awal dan masih harus dilanjutkan dengan penelitian lanjutan. Mengetahui kebijakan "Prospek"
(Program Strategis Pembangunan Kampung) adalah sebuah pengetahuan yang menjadi dasar untuk tindakantindakan selanjutnya. Penelitian ini menjadi penting karena bisa membuka jalan untuk penelitian lebih lanjut mengenai masalah di Papua secara komprehensif.

\section{Rumusan Masalah}

1. Bagaimana implementasi kebijaksanaan Prospek (Program Strategi Pembangunan Kampung) dalam pemberdayaan masyarakat Kabupaten Jayapura?

2. Faktor-faktor apa saja sebagai pendukung dan penghambat implementasi kebijaksanaan Prospek (Program Strategi Pembangunan Kampung) dalam memberdayakan masyarakat Kabupaten Jayapura?

3. Strategi apa yang digunakan dalam Prospek (Program Strategi Pembangunan Kampung) dalam pemberdayaan masyarakat "Bangkit

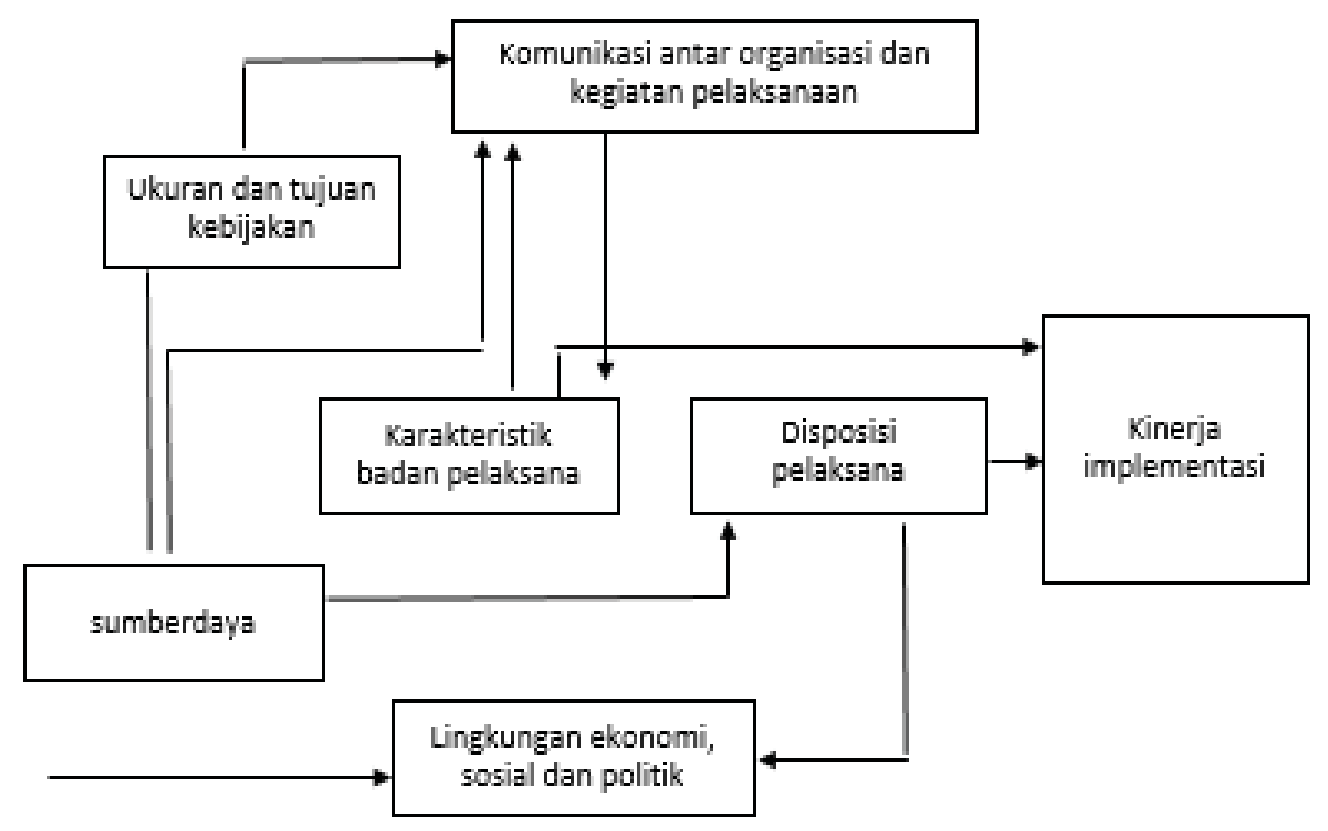

Gambar 2.

Model implementasi kebijakan versi Van Meter dan Van Horn

Sumber: Van Meter dan Van Horn (1975, p. 463) dan diolah 
Mandiri dan Sejahtera" di Kabupaten Jayapura?

\section{KAJIAN PUSTAKA}

\section{Implementasi Kebijakan}

Proses implementasi kebijakan dapat dilihat dari beberapa pendekatan dari kebijakan yang dilaksanakan. Menurut Lester dan Stewart (2000) dalam Leo Agustino (2008: 140) ada beberapa pendekatan dalam implementasi kebijakan publik yaitu (1) Pendekatan top-down (the Command and control approach); dan (2) Pendekatan bottom-up (the market approach). Masingmasing pendekatan mengajukan modelmodel kerangka kerja dalam membentuk keterkaitan antara kebijakan dan hasilnya.

Dalam pendekatan top-down, implementasi kebijakan yang dilakukan tersentralisasi dan dimulai dari actor tingkat pusat. Pendekatan top-down bertitik tolak dari perspektif bahwa keputusan-keputusan politik (kebijakan) yang telah ditetapkan oleh pembuat kebijakan harus dilaksanakan oleh administrator-administrator atau birokratbirokrat pada level bawahnya. Jadi inti pendekatan top-down adalah sejauh mana tindakan para pelaksana (administrator dan birokrasi) sesuai prosedur serta tujuan yang telah digariskan oleh para pembuat kebijakan di tingkat pusat.

Seperti yang dikutip dari Leo Agustino (2008:142) modelpendekatan top-downyang dirumuskan Van Meter \& Van Horn disebut dengan a model of the policy implementation. Proses implementasi ini merupakan sebuah abstraksi atau performansi suatu implementasi kebijakan yang pada dasarnya secara sengaja dilakukan untuk meraih kinerja implementasi kebijakan publik yang tinggi yang berlangsung dalam hubungan berbagai variabel. Model ini mengandaikan bahwa implementasi kebijakan berjalan linear dari keputusan politik yang tersedia, pelaksana, dan kinerja kebijakan publik.
Seperti pada gambar implementasi versi Van Meter \& Van Horn tersebut, implementasi kebijakan menurut Van Meter \& Van Horn, ada enam variabel yang memengaruhi kinerja implementasi, yaitu (a) Standar dan sasaran kebijakan; (b) Sumber daya; (c) Komunikasi; antarorganisasi; (d) Karakteristik agen pelaksana; (e) Sikap atau disposisi; dan (f) Lingkungan kondisi sosial, ekonomi dan politik.

\section{Kebijakan Publik}

Kebijakan publik merupakan suatu aktivitas atau program kegiatan yang dilakukan oleh pemerintahan karena adanya masalah-masalah yang berkembang di lingkungan masyarakat dan membutuhkan penyelesaian. Dengan kata lain kebijakan publik merupakan suatu arah tindakan yang dilakukan oleh pemerintah guna memenuhi atau mengatasi hambatan-hambatan atau masalah-masalah yang berkembang di lingkungan masyarakat.

Secara umum, kebijakan publik seringkali diartikan secara berbeda oleh kelompok yang berbeda, mulai dari pengertian yang terkesan sederhana hingga yang sangat rumit, baik secara konseptual maupun substansial (Ripley \& Franklin, 1986: 48). Hal itu karena kebijakan publik berada dalam ruang yang dinamis dan kompleksitas. Namun demikian, di luar dari pengertian yang pemberdayaan tersebut terdapat kesamaan pemahaman awal bahwa kebijakan publik merupakan produk buatan pemerintah, dan bahwa baik kebijakan untuk melakukan maupun untuk tidak melakukan sesuatu memiliki bobot yang sama (Howlett \& Ramesh, 1995: 4). Pandangan tersebut memberikan penjelasan bahwa persoalan kebijakan publikmerupakan persoalan pilihan (dilakukan atau tidak dilakukan). kebijakan publik hanya dibuat atau dikeluarkan oleh pemerintah, tidak boleh badan atau lembaga lain di luar pemerintah, walaupun kebijakan publik yang dikeluarkannya itu mungkin di ambil atas desakan pihak lain di luar lembaga pemerintah. 
Dalam praktik pemerintahan masalahmasalah tersebut diidentifikasi, kemudian dirumuskan dalam bentuk suatu peraturan secara operasionalnya bisa dalam bentuk proyek, ataupun program. Agar program tersebut dapat diketahui oleh masyarakat maka membutuhkan implementasi. Dalam kaitan itu Nugroho (2004: 105) mengemukakan "konteks bagaimana merumuskan kebijakan publik (formasi kebijakan) dan bagaimana kebijakan publik tersebut diimplementasikan“. Hal ini mengindikasikan bahwa dalam setiap perumusan kebijakan apakah menyangkut program maupun kegiatan-kegiatan selalu diiringi dengan suatu tindakan pelaksanaan atau implementasi.

\section{Kebijaksanaan}

Pengertian Kebijaksanaan atau kata yang sering digunakan kebijakan menurut Suradinata (2016: 143), setiap suatu pelaksanaan kegiatan/kebijakan pasti "mempunyai kendala". Dalam pengambilan keputusan kendala yang biasa terjadi adalah

- Dinamika individu di dalam organisasi;

- Dinamika kelompok orang di dalam organisasi; dan

- Dinamika lingkungan organisasi.

Dalam hubungannya dengan dinamika individu, seorang pimpinan harus dapat memperkirakan sikap tindakan dari stafnya dalam kaitannya dengan pelaksanaan keputusannya. Keputusan/ Kebijakan akan berjalan dengan baik, jika dibantu oleh kelompok orang yang telah "dewasa" dalam organisasi tersebut. Pimpinan juga mempunyai tanggung jawab "mendewasakan" kelompok yang ada.

Lebih lanjut Suradinata (2018: 126) menyatakan dalam pengertian operatifnya, kebijaksanaan diartikan sebagai berikut.

Pembangunan seutuhnya mencakup Pembangunan pengembangan kepribadian, yaitu di dalamnya adanya karakter dan jati diri. Karakter adalah watak, yaitu sikap batin yang memengaruhi segenap pikiran dan perbuatan, tabiat dan budi pekertinya. Watak juga dapat diartikan sebagai kekuatan moral yang tampak pada prilaku seseorang atau kelompok dan tercermin pula dalam karya-karya yang dihasilkannya; sedangkan jati diri adalah diri kita yang sesungguhnya, sifat-sifat dasar manusia yang asli dan berasal dari Tuhan.

\section{Pemberdayaan}

Darmawan (2007) mengutip pendapat Fear \& Schwarzweller (1985) yang mememukan bahwa pemberdayaan dipahami sebagai:

"a process in which increasingly more members of a given area or environment make and implement socially responsible decision, where the probable consequence of which is an increase in the life chances of some people without a decrease (without deteriorating) in the life chances of others".

Dalam hubungan ini, Robbins et al. (1998) secara singkat menyatakan sebagai berikut.

Empowerment "process by which individuals and groups gain power,access to resources and control over their own lives. in doing so,they gain the ability to achieve their highest personel and collective aspirations and goals".

Menurut definisinya, pemberdayaan diartikan sebagai upaya untuk memberikan daya (empowerment) atau penguatan (strengthering) kepada masyarakat (Mas'oed,1990). Keberdayaan masyarakat oleh Sumodiningrat (1997) diartikan sebagai kemampuan individu yang bersenyawa dengan masyarakat dalam membangun keberdayaan masyarakat yang bersangkutan. 
Karena itu, pemberdayaan dapat disamakan dengan perolehan kedekatan dan akses terhadap sumber daya untuk mencari nafkah (Pranarka, 1996).

\section{Strategi}

Ditinjau secara etimologi, istilah strategi berasal dari kata Yunani strategos (jenderal), kata kerja Yunani stratego dapat diartikan sebagai perencanaan dan pemusnahan musuh-musuh dengan menggunakan cara yang efektif berlandaskan sarana-sarana yang dimiliki.

Strategi pertama kali didefinisikan oleh Chandler dalam Rangkuti, strategi adalah alat untuk mencapai tujuan perusahaan dalam kaitannya dengan tujuan jangka panjang, program tidak lanjut, serta prioritas alokasi sumber daya, sedangkan Tjokroamidjojo menyatakan bahwa, strategi merupakan "perhitungan" mengenai rangkaian kebijaksanaan dan langkah-langkah pelaksanaan. Bryson menyatakan bahwa, "Strategi secara luas dapat dipandang sebagai pola tujuan, kebijakan, program, tindakan, keputusan atau alokasi sumber daya yang mendefinisikan bagaimana organisasi itu, apa yang dikerjakan organisasi, dan mengapa organisasi itu melakukannya.

Berdasarkan beberapa pendapat di atas, maka strategi dapat diartikan sebagai suatu rencanayangdisusunolehmanajemenpuncak untuk mencapai tujuan yang diinginkan. Rencana ini meliputi tujuan, kebijakan, dan tindakan yang harus dilakukan oleh suatu organisasi dalam mempertahankan eksistensi dan menenangkan persaingan, terutama perusahaan atau organisasi harus memiliki keunggulan kompetitif.

Mintzberg menyatakan bahwa konsep strategi sekurang-kurangnya mencakup lima arti yang saling terkait di mana strategi adalah plan, ploy, pattern, position dan perspective, atau yang lebih dikenal dengan Five Ps fo Strategy. Adapun penjelasan dari kelima arti tersebut adalah sebagai berikut.
1) Plan, strategi dihadapkan pada bagaimana pimpinan menetapkan arah organisasi dalam mewujudkan tujuan organisasi.

2) Ploy, strategi dihadapkan pada dunia persaingan, di mana ancaman dan tipu daya digunakan untuk mendapatkan keuntungan.

3) Pattern, strategi fokus kepada tindakan, mengingatkan bahwa konsep tidak adanya gunanya tanpa aksi/perilaku.

4) Position, strategi mendorong untuk melihat organisasi dalam konteks lingkungan kompetisi, bagaimana organisasi memosisikan dan melindungi diri mereka dalam menghadapi, menghindari, menumbangkan pesaing.

5) Perspective, strategi fokus pada visi yang terintegrasi antara organisasi dengan lingkungannya.

Strategi yang baik disusun berdasarkan kemampuan internal dan kelemahan perusahaan, antisipasi perubahan dalam lingkungan, serta kesatuan pergerakan yang dilakukan oleh mata-mata musuh.

\section{Teori Van Meter \& Van Horn}

Van Meter \& Van Horn (1975), dalam teorinya mengemukakan bahwa perbedaanperbedaan dalam proses implementasi akan dipengaruhi oleh sifat kebijakan yang akan dilaksanakan. Selanjutnya mereka menawarkan antara isu kebijakan dengan implementasi dan suatu model konseptual yang mempertalikan kebijakan dengan prestasi kerja (performance). Atas dasar pandangan ini Van Meter \& Van Horn berusaha untuk membuat tipologi kebijakan menurut:

1) jumlah masing-masing perubahan yang akan dihasilkan; dan

2) jangkauan atau lingkup kesepakatan terhadap tujuan di antara pihakpihak yang terlibat dalam proses implementasi. 
Hal lain yang dikemukakan oleh kedua ahli tersebut adalah bahwa jalan yang menghubungkan antara kebijakan dan prestasi kerja dipisahkan oleh sejumlah variabel bebas (independent variable) yang saling berkaitan. Variabel-variabel bebas tersebut adalah:

1) Ukuran dan tujuan kebijakan

2) Sumber-sumber kebijakan

3) Ciri-ciri atau sifat badan/instansi pelaksana

4) Komunikasi antar organisasi terkait dan kegiatan-kegiatan pelaksanaan

5) Sikap para pekerja; dan

6) Lingkungan ekonomi, sosial dan politik

Variabel-variabel kebijakan bersangkut paut dengan tujuan-tujuan yang telah digariskan dan sumber-sumber yang tersedia. Pusat perhatian pada badan-badan pelaksana meliputi baik organisasi formal maupun informal, sedangkan komunikasi antar organisasi terkait serta kegiatankegiatan pelaksanaannya mencakup antar hubungan di dalam lingkungan sistem politik dan dengan kelompok-kelompok sasaran.

\section{Analisis ASOCA}

Analisis Ini sangat dibutuhkan di Indonesia yang mempunyai berbagai macam budayaterutama Papua dalam menyelesaikan suatu konflik sangat dibutuhkan pendekatan budaya dalam penyelesaiannya.
1. Ability (Kemampuan)
2. Strengths (Kekuatan)
3. Opportunity (Peluang)
4. Culture (Budaya)
5. Agility (Kecerdasan)

\section{METODE PENELITIAN}

Penelitian ini menggunakan metode deskriptif dengan pendekatan kualitatif di mana peneliti ingin menggambarkan dan menjelaskan tentang bagaimana implementasi kebijakan Program Strategi Pembangunan Kampung dalam pemberdayaan masyarakat Papua "Bangkit Mandiri dan Sejahtera" di Distrik Sentani Timur Kabupaten Jayapura sebagaimana di atur dalam perundang-undangan yang berlaku. Bogdan \& Taylor dalam Moleong (2004: 3) mendefinisikan metodologi kualitatif sebagai prosedur penelitian yang menghasilkan data deskriptif berupa katakata tertulis atau lisan dari orang-orang dan perilaku yang dapat diamati. Pendapat ini memberikan pemahaman bahwasanya data-data yang dikemukakan oleh seorang informan dalam penelitian kualitatif menjadi gambaran tentang permasalahan yang akan diteliti.

\section{HASIL PENELITIAN DAN PEMBAHASAN}

Penelitian ini bertujuan untuk mendapatkan informasi ukuran mengenai tingkat keberhasilan Implementasi Kebijakan Prospek (Program Strategis Pembangunan Kampung) dalam memberdayakan masyarakat dan mengidentifikasi faktorfaktor yang memengaruhi tingkat keberhasilan tersebut di Kabupaten Jayapura pada 2020.

Metode yang digunakan adalah metode penelitian deskriptif di mana pemilihan sampel dan pengumpulan data dilakukan menurut metode purposive sampling terhadap Kampung-kampung di tiga Distrik (Distrik Sentani Barat, Sentani, dan Sentani Timur), yang didasarkan pada jumlah populasi penduduk yang sangat padat Distrik Sentani 76.628 jiwa, Sentai Timur 9.680 jiwa, dan Sentani Barat 5.596 jiwa. Dengan demikian peneliti dapat mengukur sejauh mana Implementasi kebijakan Program Strategis Pembangunan Kampung yang ada di Kabupaten Jayapura. 


\section{Implementasi Kebijaksanaan "Pros- pek" dalam Memberdayakan Masyar- akat Kabupaten Jayapura}

Pemerintah pusat yang diperankan oleh Kementerian Dalam Negeri merupakan leading sector, maka kebijakan Kementerian Dalam Negeri di bidang kesejahteraan masyarakat merefleksikan kebijakan Program Strategi Pembangunan Kampung dalam pemberdayaan masyarakat.

Dalam konteks otonomi daerah penyelenggaraan pemerintah kepada masyarakat di bidang kesejahteraan masyarakat telah didesentralisasikan kepada pemerintah daerah, dalam hal itu pemerintah Provinsi, Kabupaten dan kota merupakan instansi yang berbeda di bawah koordinasi Kementerian Dalam Negeri untuk menyelenggarakan proses kesejahteraan masyarakat secara Nasional.

Pelaksanaan "Prospek" didasarkan pada Inpres No. 5 Tahun 2007 tentang Percepatan Pembangunan bagi Provinsi Papua dan Papua Barat, tersebut di atas kemudian ditindaklanjuti dengan Keputusan Mendagri RI No.414 Tahun 2012, Penetapan Pengurusan Anggaran/Barang dan Pejabat Penerimaan Negara kegiatan Urusan Bersama (UB) Program Nasional Pemberdayaan Masyarakat. Namun demikian secara operasional di lapangan belum adanya petunjuk teknis tentang "Prospek" dalam pemberdayaan masyarakat, sesuai dengan amanat undangundang tersebut di atas, maka pelaksanaan di daerah mengacu pada Undang-Undang No. 21 Tahun 2001 tentang Otonomi Khusus bagi Provinsi Papua, serta Peraturan Gubernur No. 79 Tahun 2007 tentang Penyelenggaraan Pemerintah Kampung. Hal tersebut di atas menunjukkan pada pelaksana keputusan kebijakan dasar yang dapat berbentuk Undang-Undang ataupun keputusankeputusan dan lazimnya keputusan tersebut mengidentifikasi permasalahan publik yang perlu diatasi, tujuan yang ingin dicapai dan cara implementasinya.
Beranjak dari pemikiran bahwa pembagian Dana Otsus sepatutnya menggunakan asas keadilan dan pemerataan, serta memperhatikan kinerja output, outcome dan impact yang dihasilkan dalam pengelolaan Dana Otsus sebelumnya (Periode 2002-2013) kurang optimal, maka pada masa pemerintahan Gubernur/Wakil Gubernur Lukas Enembe dan Klemen Tinal (2013-2018) pembagian Dana Otsus diubah menjadi $80 \%$ untuk Pemerintah Kabupaten/kota dan 20\% untuk pemerintah provinsi. Pembagian tersebut setelah terlebih dahulu mengalokasikan dana untuk Urusan Bersama, yaitu Program Gerbangmas Hasrat Papua, Kartu Papua Sehat, Perumahan Rakyat, dan "Prospek". Harapannya, melalui alokasi Dana Otsus seperti itu semua Pemerintah Kabupaten/ kota akan menjadi lebih leluasa berkreasidan berinovasi untuk mengelola Dana Otsus dalam upaya mempercepat kemajuan wilayah Papua dibandingkan wilayah lainnya di Indonesia. Harapan lainnya adalah untuk mempercepat peningkatan kesejahteraan masyarakat Papua menjadi di atas rata-rata nasional, serta untuk semakin memperluas kesempatan atau peluang usaha bagi Orang Asli Papua, sebagaimana yang diamanatkan oleh Undang-Undang No. 21 Tahun 2001 mengenai Otonomi Khusus Provinsi Papua.

Selanjutnya untuk memastikan bahwa pengelolaan Dana Otsus dilaksanakan sesuai yang diharapkan, maka pada akhir tahun 2013 telah disahkan Perdasus No. 25 Tahun 2013 tentang Pembagian Penerimaan dan Pengelolaan Keuangan Dana Otonomi Khusus, yang diikuti dengan turunannya baik itu pada 2013, 2014 maupun 2015 dalam berbagai bentuk Peraturan Gubernur dan Surat Keputusan Gubernur seperti Peraturan Gubernur tentang jaminan pembiayaan pelayanan kesehatan masyarakat Papua, sistem rujukan pelayanan kesehatan, penggunaan Dana Otsus untuk pendidikan, "Prospek", Gerbangmas, pedoman pengelolaan Dana Otsus, dan sebagainya, 
atau Surat Keputusan Gubernur tentang bantuan untuk lembaga keagamaan, bantuan sosial kepada Fasyankes, penerima belanja program strategi pembangunan ekonomi dan kelembagaan kampung, dan lain-lain.

\section{Faktor-Faktor Pendukung dan Peng- hambat Implementasi Kebijaksanaan "Prospek"}

Selain faktor pendukung, maka dalam implementasi kebijakan kecenderungan tidak berhasil atau gagalnya implementasi kebijakan itu dapat terjadi karena adanya faktor-faktor yang memengaruhinya. Dikemukakan oleh Sunggono (1994: 149153), bahwa implementasi kebijakan memiliki beberapa faktor penghambat, yaitu sebagai berikut.

\section{Isi Kebijakan}

Pertama, implementasi kebijakan gagal karena masih samarnya isi kebijakan, maksudnya apa yang menjadi tujuan tidak cukup terperinci, sarana-sarana dan penerapan prioritas, atau programprogram kebijakan terlalu umum atau sama sekali tidak ada. Kedua, karena kurangnya ketetapan intern maupun ekstern dari kebijakan yang akan dilaksanakan.

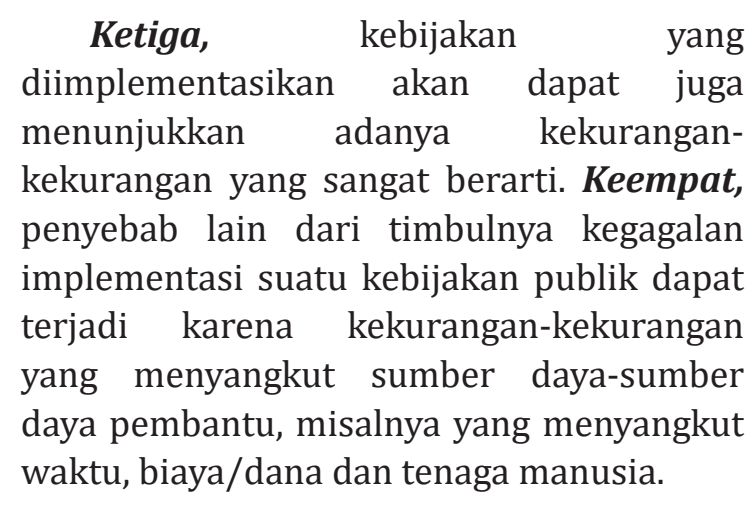

\section{- Informasi}

Implementasi kebijakan publik mengasumsikan para pemegang peran yang terlibat langsung mempunyai informasi yang perlu atau sangat berkaitan untuk dapat memainkan perannya dengan baik. Informasi ini justru tidak ada, misalnya akibat adanya gangguan komunikasi.

\section{- Dukungan}

Pelaksanaan suatu kebijakan publik akan sangat sulit apabila pada pengimplementasiannya tidak cukup dukungan untuk pelaksanaan kebijakan tersebut.

\section{- Pembagian Potensi}

Sebab musabab yang berkaitan dengan gagalnya implementasi suatu kebijakan publik juga ditentukan aspek pembagian potensi di antara para pelaku yang terlibat dalam implementasi. Dalam hal ini berkaitan dengan diferensiasi tugas dan wewenang organisasi pelaksana. Struktur organisasi pelaksanaan dapat menimbulkan masalahmasalah apabila pembagian wewenang dan tanggung jawab kurang disesuaikan dengan pembagian tugas atau ditandai oleh adanya pembatasan-pembatasan yang kurang jelas.

Implementasi kebijakan merupakan sebuah pilihan alternatif dalam menyelesaikan permasalahan yang dihadapi oleh masyarakat, oleh karena itu kurang perhatian terhadap langkah implementasi merupakan salah satu sebab utama, kenapa suatu alternatif penyelesaian yang baik seringkali tidak mampu menyelesaikan masalah yang seharusnya diselesaikan.

Persentase penduduk miskin Provinsi Papua pada umumnya mengalami fluktuatif dan cenderung menurun. Rata-rata tingkat penduduk miskin di Provinsi Papua selama enam tahun terakhir adalah sebesar $28,57 \%$, di mana persentase penduduk miskin pada 2013 sebanyak 31,52\% dan pada 2016 turun menjadi $28,54 \%$ atau naik sebesar 1,31\% dibanding tahun 2015, kemudian pada 2017 tingkat kemiskinan terlihat menurun kembali hingga menjadi 27,62\% selanjutnya pada 2018 meningkat kembali hingga menjadi $27,74 \%$ atau meningkat sebesar $0,43 \%$ dibanding tahun 2017 . Rata- 
rata penurunan tingkat kemiskinan setiap tahunnya mencapai-2,39\%.

Kabupaten Deiyai memiliki tingkat kemiskinan tertinggi. Pada 2013 tingkat kemiskinannya tercatat sebesar 47,52\%, kemudian terlihat fluktuatif menurun hingga 2018 mencapai 43,49\% dengan rata-rata penurunan kemiskinan yang terlihat lambat, yaitu sebesar-1,71\% per tahun. Sedangkan kabupaten Merauke merupakan kabupaten dengan tingkat kemiskinan terendah $\mathrm{di}$ Papua yang juga terlihat menurun, yaitu dari $12,33 \%$ pada 2013 menjadi 10,54\% pada 2018 , atau dengan rata-rata penurunan sebesar-2,71\% per tahun. Jika dipilah per kabupaten, yang tingkat kemiskinannya berada di atas rata-rata ada tujuh belas kabupaten, yaitu Jayawijaya, Paniai, Puncakjaya, Yahukimo, Pegununganbintang, Tolikara, Waropen, Supiori, Mambramo Raya, Nduga, Lannyjaya, Mambramo Tengah, Yalimo, Puncak, Dogiyai, Intan Jaya, dan Deiyai.

Berdasarkan faktor-faktor tersebut di atas, maka hasil dari sebuah upaya pemberdayaan akan sangat tergantung dari kondisi masyarakat dan peran serta semua stakeholder yang terlibat dalam program pemberdayaan tersebut. Menurut Subejo dan Supriyanto dalam Sukmawati (2008), pemberdayaan masyarakat merupakan upaya yang disengaja untuk memfasilitasi masyarakat lokal dalam merencanakan, memutuskan dan mengelola sumber daya lokal yang dimiliki melalui tindakan bersama dan networking sehingga pada akhirnya mereka memiliki kemampuan dan kemandirian secara ekonomi, ekologi dan sosial. Pendekatan utama dalam konsep pemberdayaan adalah bahwa masyarakat tidak dijadikan objek dari pelaksanaan proyek, namun juga merupakan subjek dari proyek tersebut. Proses pemberdayaan umumnya dilakukan secara kolektif, walaupun pada beberapa situasi pemberdayaan dapat saja dilakukan secara individual.
Suatu kegiatan dirumuskan dan dibuat bukan sekadar untuk dijadikan, namun agar dapat memberikan dampak berubah perubahan-perubahan sesuai dengan tujuan kebijakan maka perlu diimplementasikan. Hal ini karena, implementasi kebijakan merupakan suatu upaya untuk mencapai tujuan-tujuan tertentu dengan sarana tertentu dan dalam urutan waktu tertentu, (Sunggono, 1994: 137).

\section{Strategi dalam Program Pembangunan Kampung dalam Pemberdayaan Masyarakat di Kabupaten Jayapura}

Strategi pertama kali didefinisikan oleh Chandler dalam Rangkuti, strategi adalah alat untuk mencapai tujuan perusahaan dalam kaitannya dengan tujuan jangka panjang, program tidak lanjut, serta prioritas alokasi sumber daya, sedangkan Tjokroamidjojo menyatakan bahwa, strategi merupakan "perhitungan" mengenai rangkaian kebijaksanaan dan langkahlangkah pelaksanaan.

Menurut Bryson menyatakan bahwa, "strategi secara luas dapat dipandang sebagai pola tujuan, kebijakan, program, tindakan, keputusan atau alokasi sumber daya yang mendefinisikan bagaimana organisasi itu, apa yang dikerjakan organisasi, dan mengapa organisasi itu melakukannya".

Berdasarkan beberapa pendapat di atas, maka strategi dapat diartikan sebagai suatu rencanayangdisusunolehmanajemenpuncak untuk mencapai tujuan yang diinginkan. Rencana ini meliputi tujuan, kebijakan, dan tindakan yang harus dilakukan oleh suatu organisasi dalam mempertahankan eksistensi dan menenangkan persaingan, terutama perusahaan atau organisasi harus memiliki keunggulan kompetitif.

Untuk menggunakan metode analisis ASOCA, yakni ability (kemampuan), strengths (kekuatan), opportunity (peluang), culture (budaya), dan agility (kecerdasan), dalam Program Strategis Pembangunan Kampung 
di tiga Distrik Sentani Barat, Sentani dan Sentani Timur langkah awal yang mesti dilakukan adalah mengetahui faktor-faktor yang menjadi bagian dari masing-masing unsur ASOCA. Analisis ini selanjutnya dari masing-masing faktor lingkungan baik internal maupun eksternal, selanjutnya diklasifikasikan berdasarkan unsur-unsur ASOCA.

Kemiskinan bukanlah merupakan masalah baru dalam kehidupan masyarakat Indonesia, kemiskinan telah melekat erat dalam segenap aspek kehidupan masyarakat baik di perdesaan maupun perkotaan, untuk menanggulangi permasalahan kemiskinan tersebut pemerintah telah mengimplementasikan berbagai program pengentasan kemiskinan salah satunya "Prospek", namun masalah kemiskinan dalam masyarakat belum juga bisa teratasi secara tuntas.

Implementasi "Prospek" telah dilaksanakan sesuai dengan ketentuan walaupun hasilnya belum maksimal seperti yang diharapkan, secara fisik telah terlihat hasilnya berupa prasarana/sarana dasar yang dibutuhkan masyarakat di tiga distrik Sentani Barat, Sentani, dan Sentani Timur seperti jembatan, saluran air, gorong-gorong, talud, dan sebagainya sehingga sangat membantu masyarakat yang umumnya bermatapencaharian bertani untuk meningkatkan pendapatan dan memenuhi kebutuhan pokok, namun secara nonfisik

Implementasi "Prospek" tersebut belum menunjukkan perubahan yang signifikan secara keseluruhan berupa produktivitas maupun kegiatan ekonomi produktif lainnya, untuk kegiatan ekonomi produktif kelompok perempuan melalui kegiatan simpan pinjam telah terlihat ada perubahan yang ditandai dengan mulai berjalannya kegiatan ekonomi berupa usaha rumah tangga oleh anggota kelompok SPP di tiga Distrik dengan kegiatan yang bervariasi, dan sesuai dengan informasi yang dikumpulkan peneliti telah menyusul pengajuan usulan pinjaman oleh lima kelompok baru, upaya pengentasan kemiskinan yang telah dilaksanakan belum maksimal seperti yang diharapkan namun setelah kegiatan "Prospek" dilaksanakan menunjukkan perubahan sikap prilaku masyarakat terutama perempuan yang semakin peduli dengan peningkatan kesejahteraan keluarga, yang kemudian berusaha meningkatkan pendapatan rumah tangga melalui kegiatan ekonomi berskala kecil seperti berjualan penganan kecil, souvenir, anyaman tikar, noken, pinang dan sebagainya untuk memenuhi kebutuhan ekonomi keluarga.

\section{SIMPULAN}

1. Implementasi kebijakan Program Strategis Pembangunan Kampung (Prospek) pada delapan tahun ini belum ada perubahan atau peningkatan kesejahteraan Pemberian bantuan belum sepenuhnya di rasakan oleh masyarakat Miskin, karena dari hasil penelitian masih ada anggota kelompok yang tidak termasuk dalam kategori Miskin tetapi menjadi anggota kelompok penerima bantuan "Prospek".

2. Tidak efektifnya implementasi kebijakan "Prospek" sebenarnya berkaitan dengan beberapa faktor yang memengaruhi implementasi kebijakan, yakni: (1) Kurangnya Pelatihan kepada Aparat Kampung dalam Mengelola Anggaran yang begitu Besar (Gagal) (2) perbedaan persepsi antara pemerintah, kampung, dengan masyarakat terhadap tujuan dan sasaran kebijakan yang menyangkut pemahaman dan disposisi atas isi perjanjian; dan (3) Tidak konsistensi pemerintah dalam mengimplementasikan kebijakan "Prospek".

3. Strategi yang dilakukan Kabupaten Jayapura ketika Tahun ini Dana "Prospek" (Otsus) sudah dihentikan 
semenjak 2018 oleh Provinsi Papua dan berakhirnya Dana Otsus di Papua, Kabupaten Jayapura membuat kebijakan yang disebut dengan Kampung Adat yang di mana segala sesuatu dikembalikan kepada aturan adat yang tidak bertentangan dengan Pemerintah dan Kebijakan Kampung Adat juga adalah memberdayakan masyarakat Kampung di 19 distrik dan 136 kampung di Kabupaten Jayapura.

\section{SARAN}

1. Pemerintah dan kampung hendaknya lebih intensif mengadakan sosialisasi secara informal kepada masyarakat mengenai program strategi pembangungan kampung dalam pemberdayaan masyarakat, juga harus membuat keseimbangan antara program yang bersifat top down dengan yang bersifat bottom up, serta sekaligus mampu melakukan kontrol terhadap implementasi kebijaksanaan yang telah dibuat. Prospek (Program Strategi Pembangunan Kampung), setiap tahun harus ada kelanjutan karena masyarakat kampung sangat mengharapkan program ini.

2. Pemerintah dan Kabupaten dan Distrik hendaknya lebih intensif mengadakan sosialisasi secara informal kepada masyarakat mengenai program strategi pembangungan kampung dalam pemberdayaan masyarakat, juga harus membuat keseimbangan antara program yang bersifat Top Down dengan yang bersifat Bottom $U p$, serta sekaligus mampu melakukan kontrol terhadap implementasi kebijaksanaan yang telah dibuat, dan pengawasan terhadap pelaksanaan Prospek (Program Strategis Pembangunan Kampung) dalam memberdayakan masyarakat "Bangkit, Mandiri, dan Sejaterah" di Kabupaten Jayapura perlu ditingkatkan guna meminimalkan penyimpangan dari tujuan dan sasaran "Prospek".

3. Strategi pembangunan kampung, yang dilakukan Pemerintah Kabupaten Jayapura dengan membuat kebijakan Kampung Adat untuk mengantispasi berkahir dana Otonomi Khusus tahun 2021 setiap tahun harus ada kelanjutan karena masyarakat kampung yang semakin baik, dapat memperbaiki, serta meningkatkan pemberdayaan masyarakat. Di samping itu untuk kesejahteraan masyarakatnya harus diswadayakan dan dalam Dana "Prospek" dikhususkan untuk kebutuhan Infrastruktur masyarakat di tiga Distrik Sentani Timur, Sentani, dan Sentani Barat Kabupaten Jayapura.

\section{DAFTAR RUJUKAN}

Arikunto, Suharsimi, 2002, Prosedur Penelitian Suatu Pendekatan Praktik, Rieneka Cipta, Jakarta.

Ermaya Suradinata, 2018, Etika Pemerintahan dan Geopoitik Indonesia, Alqaprint, Jatinangor.

Ermaya Suradinata, 2016, Analisis Kepemimpinan Strategi Pengambilan Keputusan, alQaprint Cipta, Jatinangor.

Dharmawan,Fear and Schwarzweller,1985: 32, Pengertian Pemberdayaan Universitas Sebelas Maret,Surakarta.

Dunn,William N, 1999: 63-64, Analisis Kebijakan Publik, Graha Widya, Yogyakarta.

Effendi, Khasan, 2010: 100, Sosiologi Pemerintahan. Bandung Indra Prahasta.

Gunawan Sumodiningrat Strategi, Kebijaksanaan dan Program Pembangunan Masyarakat Desa. Dosen Fakultas Ekonomi, Magister Manajemen, dan Pascasarjana UGM Kepala Biro Pembangunan Daerah Tingkat II dan Perdesaan, Bappenas

Hoogerwerf, A, 1983, Ilmu Pemerintahan. (alih bahasa: L.L. Tobing). Jakarta. Erlangga. 
Howlett, Michael, \& M.Ramesh, 1995: 4, Studyng Public Policy: Policy Cycles and Policy Subsystems. Toronto: Oxford University Press.

Islamy Irfan, 2004, Prinsip-Prinsip Perumusan Kebijaksanaan Negara, Bumi Aksara, Jakarta

Moleong, Lexy J, 2004,Metodologi Penelitian Kualitatif, Remaja Rosdakarya, Bandung.

Morgan, Michael. 1996, Strategi Inovasi Sumber Daya Manusia (Creating World Force Inovation). Jakarta: Elex Media Komputindo.

Mustopadijaya, AR. 1992, Studi Kebijaksanaan, Perkembangan dan Penerapannya dalam Rangka Administrasi dan Manajemen Pembangunan. Jakarta: FE-UI.

Nazir, Moh 2003, Metodologi Penelitian, Ghalia Indonesia Jakarta.

Nugroho, Rian, 2004: 105, Kebijakan Publik (Formulasi, Implementasi dan Evaluasi). Jakarta: Elex Media Komputindo.

Nugroho,Rian, 2006: 101, Kebijakan Publik (Formulasi, Implementasi dan Evaluasi). Jakarta: Elex Media Komputindo.

Reply, Randall B. \& Grace A. Franklin, 1985. Policy Implementation and Bureaucracy. Chicago: The Dorsey Press.

Robbins,Chatterjee, \& Canda, 1998: 32,Definisi Pemberdayaan, UPT Universitas Sebelas Maret, Surakarta.

Rusidi, 2003, Metodologi Penelitian, Bahan Ajar pada Program Pascasarjana Administrasi Pemerintahan Daerah IPDN, Jatinangor Pustaka Utama Jakarta.

Stigliz E. Josef, dkk.2009, Komisi Pengukuran Kinerja Ekonomi dan Kemajuan Sosial, PT Wahana Aksi Kritika.

Subarsono, 2008: 8, Analisis Kebijakan Publik: Konsep, Teori dan Aplikasi, Pustaka Pelajar, Yogyakarta.

Subarsono. 2005: 3, Analisis Kebijakan Publik: Konsep, Teori dan Aplikasi, Pustaka Pelajar, Yogyakarta.

Sugiyono, 2007, Metode Penelitian Administratif. Jakarta: Rieneka Cipta.
Suharto, Edi, 2005. Kajian Strategi Pembangunan Kesejaterahan Sosial dan Pekerjaan Sosial, PT.Refika Aditama, Bandung.

Sunggono, Bambang, 1999: 149-154, Hukum dan Kebijaksanaan Publik. Jakarta, Sinar: Grafika

Tangkilisan, Hessel Nogi S. 2005. Manajemen Publik. Jakarta: Gramedia.

Tim Koordinasi Pembangunan kampung, 2012,Program Perencanaan, Pemberdayaan, Program Strategi Pembangunan Kampung dalam Pemberdayaan Masyarakat Papua Bangkit Mandiri \& Sejahtera, Provinsi Papua.

Unaradja, Dollet, 2000, Pengantar Metode Penelitian Ilmu Sosial, PT Grasindo, Jakarta

Wahab, Solichin Abdul, 2002: 51, Analisis Kebijaksanaan: dari Formulasi ke Implementasi Kebijaksanaan Negara, Bumi Aksara, Jakarta.

Wasistiono, 2009: 23. Perkembangan Organisasi Kecamatan Dari Masa Ke Masa. Bandung: Fokusmedia.

Wibawa, Samodra, 1994. Kebijakan Publik, Proses dan Analisis. Jakarta: Intermedia.

Winarno, Budi. 2002. Kebijakan Publik Teori dan Proses, Jakarta: Media Presindo, Yogyakarta.

Winarno, Budi. 2007: 203. Kebijakan Publik Teori dan Proses: Buku Kita.,

\section{Peraturan Perundang-Undangan}

Undang-Undang Dasar Negara Republik Indonesia Tahun 1945

Undang-Undang No. 21 Tahun 2001, Otonomi Khusus Bagi Pemerintah Provinsi Papua.

Undang-Undang No. 25 Tahun 2004 tentang Sistem Perencanaan Pembangunan Nasional

Undang-Undang No. 32 Tahun 2004 tentang Pemerintahan Daerah

Undang-Undang No. 15 Tahun 2008 tentang Struktur Organisasi Distrik di Kabupaten Jayapura 
Undang-Undang No. 23 Tahun 2014 tentang Pemerintahan Daerah

Inpres No. 5 Tahun 2007 tentang Percepatan Pembangunan Provinsi Papua dan Papua Barat dalam Program Strategi Pembangunan Kampung

Peraturan Pemerintah No. 72 Tahun 2005 tentang Desa

Peraturan Pemerintah No. 41 Tahun 2007 tentang Struktur Organisasi Tata Kerja Distrik, Kabupaten Jayapura

Peraturan Bupati No. 15 Tahun 2008 tentang Susunan Organisasi dan Tata kerja Distrik Kabupaten Jayapura

Peraturan Gubernur No. 79 Tahun 2007 tentang Penyelenggaraan Pemerintah Kampung Provinsi Papua

Keputusan Menteri Dalam Negeri Republik Indonesia No. 414 Tahun 2012 tentang Penetapan Penggunaan Anggaran/ Penggunaan barang dan Pejabat Pemungut Penerimaan Negara kegiatan urusan bersama Program nasional Pemberdayaan Masyarakat

Keputusan Bupati No. 17 Tahun 2002 tentang Nama Kecamatan diganti menjadi Distrik

Keputusan Bupati No. 371 Tahun 2002 tentang Pelimpahan sebagian Kewenangan Pemerintah Kabupaten kepada Pemerintah Distrik

\section{Sumber Lain}

Sekretariatan Tim Koordinasi Provinsi Papua, 2012 tentang Program Penyelenggaraan Program strategi pembangunan pembangunan kampung, Pemerintah Provinsi Papua

Badan Pemerintahan Masyarakat Desa Tahun 2012 tentang Sumber informasi dan Data Penelitian dalam Program strategi pembangnan kampung dalam pemberdayaan masyarakat, BPMD Provinsi Papua.

Bupati Kabupaten Jayapura, 2012,Tentang Sumber informasi dan Data Penelitian Program Strategi Pembangunan Kampung dalam pemberdayaan masyarakat, Pemerintah Kabupaten Jayapura.

Kepala Distrik Sentani Barat, Sentani, dan Sentani Timur 2012 tentang Sumber Data dan informasi Program Strategi Pembangunan Kampung dalam pemberdayaan masyarakat Papua Bangkit Mandiri \& Sejahtera, Pemerintah Kabupaten Jayapura.

Kepala Kampung Ayapo,2021 tentang Sumber Data dan informasi Program Strategi Pembangunan Kampung dalam pemberdayaan masyarakat Papua Bangkit Mandiri \& Sejahtera, di Kampung Ayapo/Itakiwa

Kepala Kampung Saron Sari Tentang Sumber Data dan informasi Program Strategi Pembangunan Kampung dalam pemberdayaan masyarakat Papua Bangkit Mandiri \& Sejahtera, di Kampung Sabron Sari 